\title{
KOMUNIKASI, INFORMASI, DAN EDUKASI TENTANG PENTINGNYA IMUNISASI UNTUK MENCEGAH COVID-19 DI KOTA SURABAYA
}

\author{
Erika Martining Wardani ${ }^{1 *}$, Difran Nobel Bistara ${ }^{2}$, Riezky Faisal Nugroho ${ }^{3}$ \\ 1,2Universitas Nahdlatul Ulama Surabaya, Surabaya, Indonnesia \\ ${ }^{3}$ Politeknik Kesehatan Kemenkes Surabaya, Surabaya, Indonesia \\ Email Korespondensi : erika@unusa.ac.id
}

Disubmit: 03 November 2021 Diterima: 23 Desember $2021 \quad$ Diterbitkan: 02 Januari 2022 DOI: https://doi.org/10.33024/jkpm.v1i1.5408

\begin{abstract}
ABSTRAK
Wabah covid-19 telah dinyatakan sebagai darurat kesehatan global karena adanya laporan ribuan kasus dan bukti penularan dari manusia ke manusia. Salah satu upaya preventif adalah dengan imunisasi. Masyarakat perlu mengetahui tentang imunisasi untuk mencegah covid-19 dengan baik maka perlu diberikan komunikasi, informasi, dan edukasi untuk mengatasi permasalahan tersebut. Komunikasi, informasi, dan edukasi saat pandemi yang efektif dengan webinar sehingga masyarakat dapat mengaksesnya dari rumah tanpa harus berkerumun. Tujuan dari pengabdian masyarakat untuk meningkatkan pengetahuan masyarakat tentang imunisasi untuk mencegah covid-19. Tingkat pengetahuan dinilai setelah peserta mengisi kuesioner melalui google form dengan melakukan perbandingan nilai pre test sebelum kegiatan dan post test setelah kegiatan. Berdasarkan hasil pre test yang diikuti oleh 66 responden dapat dinyatakan bahwa hasil pre test tentang pentingnya imunisasi sebesar 14 responden $(21,2 \%)$ mengerti tentang imunisasi untuk mencegah covid-19 sedangkan berdasarkan hasil post test terdapat 54 responden $(81,8 \%)$. Hasil uji statistik didapatkan $\mathrm{p}=0.001$, artinya terdapat perbedaan yang signifikan antara pengetahuan masyarakat sebelum dengan setelah diberikan komunikasi, informasi, dan edukasi menggunakan webinar. Pengabdian masyarakat dengan webinar series ini diharapkan dapat meningkatkan status kesehatan masyarakat terutama capaian vaksin di wilayah Kelurahan Bongkaran, Kec Pabean Cantikan, Surabaya sehingga diharapkan dapat menurunkan penularan infeksi covid-19.
\end{abstract}

Kata kunci: komunikasi, informasi, dan edukasi, covid-19.

\begin{abstract}
The covid-19 outbreak has been declared a global health emergency due to reports of thousands of cases and evidence of human-to-human transmission. One of the preventive efforts is immunization. The community needs to know about immunization to prevent covid-19 well, so it is necessary to provide communication, information, and education to overcome these problems. Effective communication, information, and education during the pandemic with webinars so that people can access them from home without having to crowd. The purpose of community service is to increase public knowledge about immunization to prevent covid-19. The level of knowledge was assessed after
\end{abstract}


the participants filled out the questionnaire through the google form by comparing the pre-test scores before the activity and the post-test after the activity. Based on the results of the pre test which was attended by 66 respondents, it can be stated that the results of the pre test about the importance of immunization were 14 respondents (21.2\%) understood about immunization to prevent covid-19, while based on the post test results there were 54 respondents (81.8\%). Statistical test results obtained $p=0.001$, meaning that there is a significant difference between public knowledge before and after being given communication, information, and education using webinars. Community service with this webinar series is expected to improve public health status, especially vaccine achievements in the Bongkaran Village area, Pabean Cantikan District, Surabaya so that it is expected to reduce the transmission of Covid-19 infections.

Keywords: communication, information, and education, covid-19.

\section{PENDAHULUAN}

Wabah COVID-19 telah dinyatakan sebagai darurat kesehatan global karena adanya laporan ribuan kasus dan bukti penularan dari manusia ke manusia (Hong et al., 2020). Coronavirus disease 2019 (COVID-19) adalah penyakit yang disebabkan oleh virus Severe Acute Respiratory Syndrome Coronavirus-2 (SARS-CoV-2) yang sedang mewabah dan telah menjadi pandemi global (Arshad Ali, Baloch, Ahmed, Arshad Ali, \& lqbal, 2020).

Tingkat kematian dan morbiditas COVID-19 terus meningkat setiap hari (Hamid et al., 2020). Berdasarkan data Badan Kesehatan Dunia per tanggal 27 Desember 2020, total sebanyak 79.231.893 kasus COVID-19 yang tersebar di seluruh dunia dengan total kematian sebanyak 1.754.574 jiwa (World Health Organization, 2020a). Satuan Tugas Penanganan Covid-19 (2021) melaporkan per tanggal 3 Januari 2021 data sebaran COVID-19 di Indonesia sebanyak 765.350 kasus terkonfirmasi, sebanyak 22.734 kasus meninggal dan 110.679 kasus aktif atau sedang dalam perawatan Sebesar $11,3 \%$ (86.361 kasus) terkonfirmasi di Provinsi Jawa Timur dan terbanyak berasal dari Kota Surabaya (18.288 kasus) (Pemerintah Kota Surabaya, 2020; SATGAS COVID-19 Jatim, 2020). Sebagian besar kasus COVID-19 menunjukkan gejala ringan dan $50 \%$ orang yang terinfeksi tidak menunjukkan gejala (Mizumoto, Kagaya, Zarebski, \& Chowell, 2020). Namun, sekitar $20 \%$ pasien, penyakit ini menyebabkan konsekuensi klinis yang parah yang memerlukan rawat inap dan beberapa kasus membutuhkan perawatan intensif (Z. Wu \& McGoogan, 2020).

Vaksin Sinovac adalah salah satu vaksin berjenis inactivated vaccine atau virus mati. Secara singkat inactivated vaccine adalah vaksin menggunakan versi lemah atau inaktivasi dari virus untuk memancing respons imun. Vaksin ini memerlukan beberapa dosis dari waktu ke waktu untuk mendapatkan imunitas berkelanjutan terhadap penyakit. Menurut Handoyo (2021) menjabarkan virus yang disuntikkan ke manusia itu utuh. Sebelumnya virus itu telah dirusak atau dimatikan secara genetik dengan bahan kimia, suhu panas atau radiasi sehingga ketika disuntikkan ke manusia tak timbulkan masalah karena materi genetik sudah rusak sehingga tak bisa bereplikasi. Vaksin inactivated telah digunakan untuk penyakit Hepatitis A, Flu, Polio, dan Rabies. Bio Farma bekerja sama dengan Sinovac agar bisa memproduksi vaksin yang bernama CoronaVac. 
Kurangnya pengetahuan tentang vaksin sinovac banyak tidak dilakukan karena beberapa faktor diantaranya pengetahuan, pendidikan, pekerjaan, sikap, penghasilan, dukungan keluarga, dan dukungan petugas tinggi kesehatan. Pengetahuan dan pendidikan sangat berperan penting dalam pemberian imunisasi karena mampu mempengaruhi sikap dalam pengambilan keputusan terhadap pemberian imunisasi (Rosalinda, 2016). Dampak bila tidak diberikan imunisasi dapat menyebabkan penyakit covid19 akan terus mewabah bahkan menimbulkan kematian. Berdasarkan latar belakang di atas, penulis tertarik melakukan pengabdian masyarakat dengan judul Komunikasi, informasi, dan edukasi tentang pentingnya imunisasi untuk mencegah covid-19 di Kota Surabaya.

\section{MASALAH}

a. Masalah Budaya

Berdasarkan analisis situasi terdapat permasalahan yang ada yaitu kebiasaan masyarakat Kelurahan Bongkaran, Kec Pabean Cantikan, Surabaya adalah masayarakat setempat hampir tidak pernah melakukan pemeriksaan kesehatan di tempat pelayanan kesehatan serta rendahnya pengetahuan yang didapatkan tentang imunisasi untuk mencegah Covid19.

b. Mutu Layanan atau Kehidupan bermasyarakat

Masalah mutu layanan pada masyarakat Kelurahan Bongkaran, Kec Pabean Cantikan, Surabaya salah satunya adalah kurangnya informasi mengenai imunisasi untuk mencegah Covid-19.

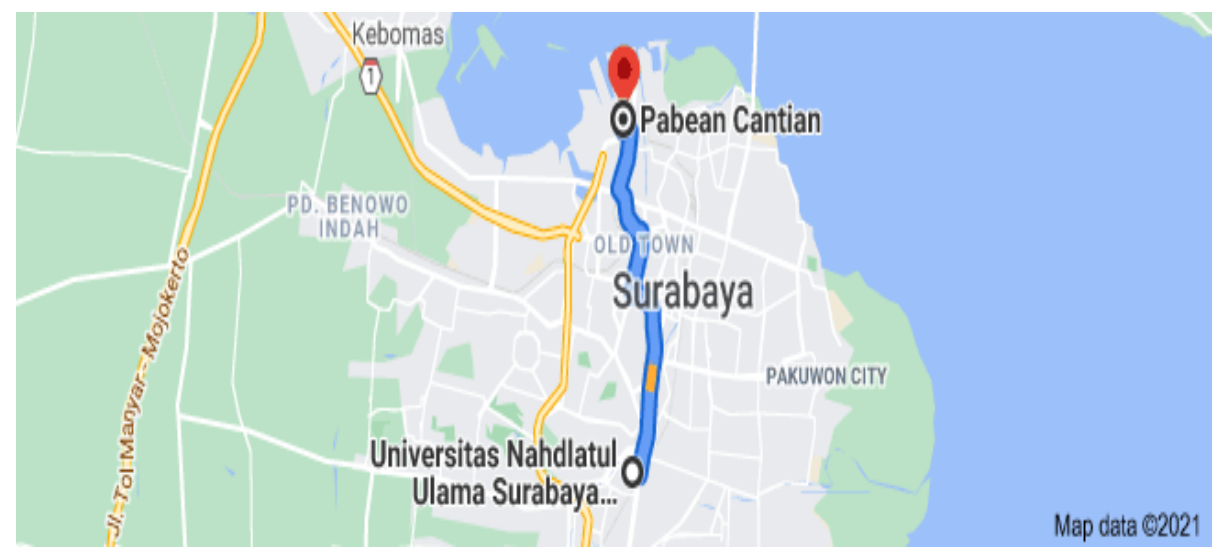

Gambar 1 Peta Lokasi Kegiatan Pengabdian Kepada Masyarakat

\section{METODE PELAKSANAAN}

Kegiatan pengmas ini dilakukan pada bulan Juni - Juli 2021. Tempat dilakukan pengabdian masyarakat teretak di Kelurahan Bongkaran, Kec Pabean Cantikan, Surabaya merupakan salah satu daerah yang terletak di utara kota Surabaya, Provinsi Jawa Timur akan tetapi karena jumlah kasus covid-19 meningkat maka dilakukan melalui online atau Dalam Jaringan (daring).

Data yang diperoleh berdasarkan survey awal yang dilakukan pada warga yang tinggal di wilayah tersebut mengatakan tidak mengetahui tentang imunisasi untuk mencegah covid-19 oleh karena itu, dengan 
kegiatan pengabdian masyarakat mengenai komunikasi, informasi, dan edukasi tentang tentang pentingnya imunisasi untuk mencegah covid-19 melalui webinar series diharapkan warga masyarakat dapat lebih mengetahui serta memahami sehingga dapat meningkatkan pengetahuan masyarakat tentang imunisasi untuk mencegah covid-19.

Metode pelaksanaan program pengabdian kepada masyarakat dilakukan dengan komunikasi, informasi, dan edukasi melalui webinar series kepada masyarakat di Kelurahan Bongkaran, Kec Pabean Cantikan, Surabaya ini melalui beberapa tahap, diantaranya:

a. Pra Kegiatan

1) Rapat Strategi Pelaksanaan

2) Survey Tempat

3) Persiapan sarana dan prasarana

b. Pelaksanaan Kegiatan

Sasaran kegiatan adalah seluruh warga masyarakat yang tinggal di wilayah Kelurahan Bongkaran, Kec Pabean Cantikan, Surabaya.

Distribusi pelaksanaan sebagai berikut:

1) Komunikasi, informasi, dan edukasi melalui webinar series tentang imunisasi untuk mencegah covid-19, baik tentang pengertian imunisasi, vaksin, tujuan, manfaat serta jenis-jenis vaksin untuk mencegah covid-19.

2) Pre test dan post test

Pre test dilaksanakan guna mengetahui tingkat pengetahuan masyarakat tentang imunisasi untuk mencegah covid-19. Kegiatan ini dilakukan sebelum pemaparan materi oleh pemateri.

Post test dilakukan untuk mengetahui tingkat pengetahuan masyarakat tentang imunisasi untuk mencegah covid-19 setelah mendapatkan komunikasi, informasi, dan edukasi. Kegiatan pre test dan post test ini dilakukan untuk mengetahui adanya peningkatan pengetahuan dari sebelum dan sesudah mendapatkan komunikasi, informasi, dan edukasi.

c. Pasca Kegiatan

Tahap ini dilakukan evaluasi dan penyusunan laporan kegiatan. Instrumen evaluasi yang digunakan adalah kuesioner melalui google form. Indikator penilaian mencakup aspek berikut :

1) Pengetahuan mengenai penularan covid-19 dan siapa saja kelompok berisiko tinggi tertular covid-19

2) Pengetahuan tentang pentingnya tetap menjalankan 5 perilaku kunci (termasuk ketika telah divaksinasi)

3) Pengetahuan tentang informasi keamanan dan efektifitas vaksin

4) Pengetahuan mengenai Counter hoax (upaya menangkal hoax) yang beredar di masyarakat

5) $3 \mathrm{~T}$ (Test, tracing, treatment)

\section{HASIL DAN PEMBAHASAN}

Pelaksanaan pengabdian masyarakat ini yang berupa webinar series dilakukan selama 1 bulan dengan menggunakan aplikasi zoom meeting. Warga masyarakat Kelurahan Bongkaran, Kec Pabean Cantikan, Surabaya yang sudah terdaftar dan sudah mengisi data melalui link google form akan diberikan kode dan pasword yang dapat digunakan untuk masuk ke zoom meeting. Materi edukasi bervariasi dan terkait dengan imunisasi untuk 
mencegah covid-19 terutama tentang pencegahan penularan infeksi tersebut mulai dari mengenal penularan covid-19 dan siapa saja kelompok berisiko tinggi tertular covid-19, pentingnya tetap menjalankan 5 perilaku kunci (termasuk ketika telah divaksinasi), informasi keamanan dan efektifitas vaksin, Counter hoax (upaya menangkal hoax) yang beredar di masyarakat serta $3 \mathrm{~T}$ (Test, tracing, treatment).

Foto kegiatan pelaksanaan
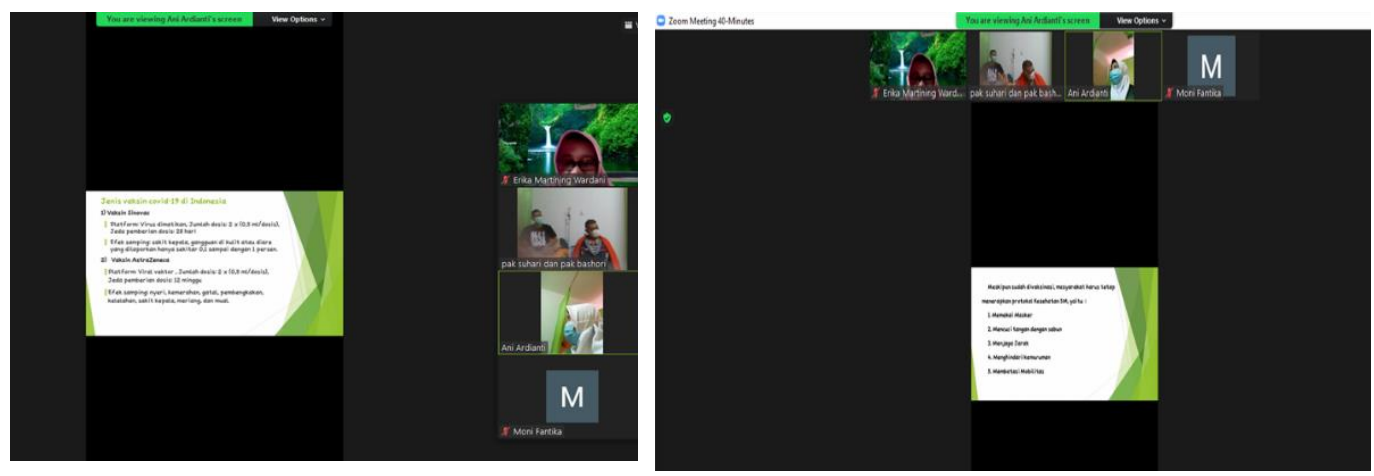

Gambar 2 Kegiatan PKM

a. Gambaran umum peserta

Peserta komunikasi, informasi, dan edukasi melalui webinar adalah masyarakat yang tinggal di wilayah Kelurahan Bongkaran, Kec Pabean Cantikan, Surabaya.

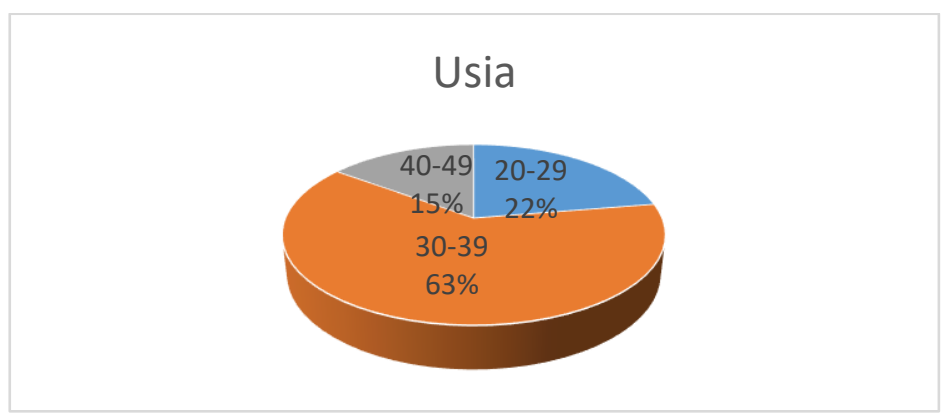

Gambar 3 Distribusi peserta webinar berdasarkan usia

Berdasarkan gambar diatas, diperoleh data bahwa peserta komunikasi, informasi, dan edukasi melalui webinar sebagian besar berusia 30-39 tahun (63\%).

b. Tingkat pengetahuan responden tentang imunisasi untuk mencegah covid19

Tingkat pengetahuan responden diukur dengan kuesioner melalui google form sebelum (pre test) dan sesudah (post test) mendapatkan komunikasi, informasi, dan edukasi melalui webinar.

Tabel 1 Pengetahuan tentang imunisasi untuk mencegah covid-19

\begin{tabular}{cccccccc}
\hline \multicolumn{2}{c}{ Pre Test } & \multicolumn{4}{c}{ Post Test } \\
\hline \multicolumn{2}{c}{ Tahu } & \multicolumn{2}{c}{ Tidak Tahu } & \multicolumn{2}{c}{ Tahu } & \multicolumn{2}{c}{ TidakTahu } \\
\hline $\mathrm{N}$ & $\%$ & $\mathrm{~N}$ & $\%$ & $\mathrm{~N}$ & $\%$ & $\mathrm{~N}$ & $\%$ \\
\hline 14 & 21,2 & 52 & 78,8 & 54 & 81,8 & 12 & 18,2 \\
\hline
\end{tabular}


Berdasarkan tabel 1, setelah diberikan komunikasi, informasi, dan edukasi melalui webinar yang diikuti sebanyak 66 peserta, dapat dinyatakan bahwa hasil pre test tentang responden yang mengetahui mengenai imunisasi untuk mencegah covid-19 sebanyak $21,2 \%$, sedangkan hasil post test didapatkan sebanyak $81,8 \%$ sehingga dapat disimpulkan bahwa terdapat peningkatan pengetahuan masyarakat tentang imunisasi untuk mencegah covid-19.

c. Komunikasi, informasi, dan edukasi terhadap pengetahuan tentang pentingnya imunisasi untuk mencegah covid-19

Tabel 2 Pengaruh komunikasi, informasi, dan edukasi melalui webinar terhadap pengetahuan

\begin{tabular}{|c|c|c|c|c|c|}
\hline Variabel & mean & SD & SE & P Value & $\mathrm{n}$ \\
\hline $\begin{array}{l}\text { Pengetahuan sebelum } \\
\text { diberikan komunikasi, } \\
\text { informasi, dan edukasi }\end{array}$ & 12.6250 & 1.58644 & .39660 & 0,001 & 66 \\
\hline $\begin{array}{l}\text { pengetahuan setelah } \\
\text { diberikan komunikasi, } \\
\text { informasi, dan edukasi }\end{array}$ & 17.7500 & 1.125468 & .28138 & & \\
\hline
\end{tabular}

Hasil uji statistik didapatkan nilai $p=0.001$, maka dapat disimpulkan ada perbedaan yang signifikan antara pengetahuan masyarakat sebelum dengan setelah diberikan komunikasi, informasi, dan edukasi menggunakan webinar series.

Analisis peneliti dari hasil evaluasi didapatkan adanya pengaruh komunikasi, informasi, dan edukasi terhadap pengetahuan tentang pentingnya imunisasi untuk mencegah covid-19. Hal ini sejalan dengan penelitian yang dilakukan oleh Wardani, dkk (2021) yang mengatakan terdapat pengaruh pendidikan kesehatan melalui webinar terhadap pengetahuan dibuktikan dengan hasil penelitian terdapat perbedaan yang signifikan antara pengetahuan masyarakat sebelum dengan setelah dilakukan pendidikan kesehatan menggunakan webinar.

Komunikasi kesehatan adalah usaha yang sistematis untuk mempengaruhi secara positif perilaku kesehatan pada remaja putri, dengan menggunakan berbagai prinsip dan metode komunikasi, baik menggunakan komunikasi antar pribadi maupun komunikasi massa (Notoatmodjo, 2012).

Masyarakat saat ini menghadapi situasi yang disebut sebagai pandemic fatigue dan infodemic. Pandemic fatigue mengacu pada pengertian bahwa masyarakat mengalami kelelahan dan secara perlahan mengalami kemunduran motivasi untuk melaksanakan tiga perilaku kunci pencegahan COVID-19. Kelelahan karena pandemi adalah respons alami terhadap krisis kesehatan masyarakat yang berkepanjangan yang belum pernah terjadi sebelumnya pada kehidupan sehari-hari semua orang, termasuk mereka yang terpengaruh secara langsung atau tidak langsung oleh virus itu sendiri. Tanda-tanda bahwa pandemi akan segera berakhir juga belum terlihat, sehingga makin memperburuk kondisi kelelahan tersebut.

Infodemik atau banjir informasi mengacu pada banyaknya informasi yang disebarkan - baik yang akurat maupun tidak - melalui berbagai media daring dan luring di masyarakat. Situasi ini menyebabkan masyarakat menjadi sulit untuk memilah info yang benar dan mana yang salah atau 
tidak akurat; dan sulit dalam memilah sumber informasi yang bisa dipercaya atau tidak. Infodemik juga mencakup upaya yang disengaja untuk menyebarkan informasi yang salah untuk merusak respon kesehatan masyarakat dengan melakukan propaganda serta agenda alternatif kelompok atau individu untuk kepentingan mereka. Dampak dari infodemik ini adalah menurunnya kedisiplinan masyarakat dalam melaksanakan pesan kunci, serta tingkat kepercayaan terhadap program vaksinasi pemerintah.

Perlu pemberian komunikasi, informasi, dan edukasi terhadap pengetahuan tentang pentingnya imunisasi untuk mencegah covid-19 secara berkelanjutan sehingga para individu perlu memiliki tingkat pemahaman yang baik mengenai vaksin, dan memahami risiko dan manfaat jika mendapatkan vaksin. Tahapan yang lebih tinggi setelah mengubah perilaku adalah ketika para individu ini kemudian mau memberikan dukungan perlindungan kepada kelompok rentan lainnya.

Luaran yang ditargetkan : pengetahuan masyarakat meningkat setelah diberikan pendidikan kesehatan dan artikel kegiatan ini dapat dipubliskasikan di jurnal pengabdian masyarakat.

\section{KESIMPULAN}

Peserta merupakan masyarakat yang tinggal di wilayah Kelurahan Bongkaran, Kec Pabean Cantikan, Surabaya, yang telah diberikan komunikasi, informasi, dan edukasi melalui webinar series mengetahui tentang imunisasi untuk mencegah covid-19 sebagian besar berusia 30-39 tahun. Hasil tes baik pre maupun post test menunjukkan peningkatan pengetahuan mengenai imunisasi untuk mencegah covid-19.

\section{DAFTAR PUSTAKA}

Arshad Ali, S., Baloch, M., Ahmed, N., Arshad Ali, A., \& lqbal, A. (2020). The outbreak of Coronavirus Disease 2019 (COVID-19)-An emerging global health threat. Journal of Infection and Public Health, 13(4), 644-646. https: //doi.org/10.1016/j.jiph.2020.02.033

Hamid, H., Abid, Z., Amir, A., Rehman, T. U., Akram, W., \& Mehboob, T. (2020). Current burden on healthcare systems in low- and middleincome countries: recommendations for emergency care of COVID19. Drugs and Therapy Perspectives, 36(10), 466-468. https://doi.org/10.1007/s40267-020-00766-2

Handoyo, A.R. (2021). Mengenal Vaksin Sinovac yang Dipakai RI Basmi Covid-19, https: / / www.cnnindonesia.com/teknologi/20201230175916-199-

588012/ mengenal-vaksin-sinovac-yang-dipakai-ri-basmi-covid-19. Diakses tanggal 9 Februari 2021, jam 16.00 WIB.

Hong, Y., Wu, X., Qu, J., Gao, Y., Chen, H., \& Zhang, Z. (2020). Clinical characteristics of Coronavirus Disease 2019 and development of a prediction model for prolonged hospital length of stay. Annals of Translational Medicine, 8(7), 443-443. https: / / doi.org/10.21037/atm.2020.03.147

Notoatmodjo. 2012. Metodologi Penelitian. Jakarta: Rineka Cipta.

Rosalina, Hesti N. (2016). Hubungan Pengetahuan Ibu Tentang Imunisasi Campak Dengan Kepatuhan Pemberian Imunisasi Campak Di Bpm Lusy 
Hemawati Mejobo Kudus. Jurnal Kesehatan Dan Kebidanan (Journal Of Midwifery And Health). Jurnal (Online) Diakses pada 10 Maret 2021 SATGAS COVID-19 Jatim. (2020). JATIM TANGGAP COVID-19. Retrieved January 3, 2021, from http://infocovid19.jatimprov.go.id/

Satuan Tugas Penanganan Covid-19. (2021). Peta Sebaran COVID-19 I Satgas Penanganan COVID-19. Retrieved January 4, 2021, from https: / covid19.go.id/peta-sebaran-covid19

Wardani, E.M., Bistara, D.N., Setiyowati. E., (2020). The Influence of Social Media About Covid-19 on Handwashing Behavior, Mask Wearing and Physical Distancing of Indonesian Students. STRADA Jurnal Ilmiah Kesehatan, 9 (2), 1338-1345. https://doi.org/10.30994/sjik.v9i2.459

Wardani, E.M., Bistara, D.N., Septiangrum, Y, (2021). Promosi Kesehatan Pencegahan Penularan Infeksi Covid-19 Pada Masyarakat Melalui Webinar Series. Dedication: Jurnal Pengabdian Masyarakat, 5

(1),

71-76. https://doi.org/10.31537/dedication.v5i1.441.

World Health Organization. (2020a). COVID-19 weekly epidemiological update, 27 December 2020. World Health Organization.

Wu, Z., \& McGoogan, J. M. (2020). Characteristics of and Important Lessons From the Coronavirus Disease 2019 (COVID-19) Outbreak in China. JAMA, 323(13), 1239. https://doi.org/10.1001/jama.2020.2648

Zainaro, M. A., Andoko, A., \& Rahmawati, R. P. (2021). Hubungan Pengetahuan dan Sikap Terhadap Kejadian Covid-19 pada Masyarakat di Kelurahan Mulyojati Kota Metro. Malahayati Nursing Journal, 3(4), 517-528. 